\title{
1. The social effects of native title: recognition, translation, coexistence
}

\section{Benjamin R. Smith and Frances Morphy}

Native title has had a profound social impact in Australia. Its effects have been felt from the local level through to the national level ever since the success of the Mabo No.2 case in the Federal Court. But despite the involvement of large numbers of anthropologists in the field of native title practice (alongside lawyers, historians, archaeologists and others trained in the social sciences and humanities) there has been surprisingly little reflection on the social effects of native title. Native title law and native title claims, negotiation of Indigenous Land Use Agreements (ILUAs) and other processes associated with the Native Title Act 1993 (Cth) (NTA) and its amendments all present themselves as candidates for analysis by social scientists. But although there is now an extensive literature on native title, almost all of this literature is concerned with Native Title practice. ${ }^{1}$ Far fewer scholars and practitioners - many of whom are publishing academics as well as consultants or employees of various agencies engaged in native title work - have engaged with native title as a social phenomenon potentially (we would argue necessarily) deserving of critical reflection.

This collection seeks to make a contribution towards the study of the social effects of native title. Based on a workshop which took place in November 2005 at The Australian National University, convened by the Centre for Aboriginal Economic Policy Research, the collection includes papers by anthropologists, claimants and other practitioners and scholars dealing with the direct and indirect effects of native title on particular places and people. In particular the collection provides a range of responses to widespread complaints by Aboriginal Australians and Torres Strait Islanders that native title delivers little in the way of meaningful recognition of customary property rights (or the systems of 'law and custom' in which these rights are embedded), that where such 'recognition' occurs it

\footnotetext{
1 There is, however, a more developed anthropological literature - which includes a significant critical dimension - on Australia's various State and Territory Aboriginal Land Rights Acts; see, for example, Berndt and Berndt (1984); Hiatt (1984); Merlan (1998); Morphy and Morphy (2001); Rumsey (1989); Smith (2003). Although they maintain a focus on Native Title practice, Sutton (2003) and Toussaint (2004) both make valuable contributions to the anthropological theorisation of native title, whilst Povinelli (2002) contains a significant critique of the social effects of Native Title. A number of the papers in Sullivan and Bauman (2006) (in particular Bauman 2006a; Correy 2006; Langton, et. al. 2006) also discuss the social effects of native title. Likewise, much of the work undertaken by the Native Title Research Unit (NTRU) at the Australian Institute of Aboriginal and Torres Strait Islander Studies is relevant to the social effects of native title. In particular, the work of the NTRU's Indigenous Facilitation and Mediation Project has examined the conflict and unsustainable outcomes arising out of poor decision making and management within the native title process (see Bauman 2005, 2006b; Bauman and Williams 2005).
} 
mistranslates and transforms local Aboriginal 'cultures of connection' to land, and that native title produces unnecessary conflict both between Indigenous groups, and also between claimants and other parties.

A critical examination of the effects or impacts of native title seems particularly timely. Following the Federal Government's 1998 amendments to the NTA (the '10 point plan') and the development of native title case law, native title has increasingly been seen as disappointing or even dangerous by many Indigenous Australians. As Lahn (Chapter 7) notes, the initial optimism that surrounded the Mabo decision has given way to a perception of relatively few benefits or even 'further dispossession' flowing from the NTA. Certainly, a number of prominent Indigenous commentators have questioned the trajectory taken by native title law. Noel Pearson, for example, has been extremely critical of the way that native title has come to take its meaning from the NTA and its amendments, writing that the High Court's decision relating to the Miriuwung-Gajerrong people

has killed off any possibility that the common law of Australia would continue to provide the parameters for reconciliation between the sovereign claim of the Crown and the rights of indigenous peoples as the original occupants of their traditional homelands ... [t] he High Court incorrectly, and with the consent of the Aboriginal parties appearing before it, treated native title as a creature of the Native Title Act rather than understanding that this legislation was never intended to change the concept of native title at common law (Pearson 2002).

For Pearson, this decision 'short-changed' Aboriginal Australians, being based on an 'anthropological rather than common law' conception of native title. Pearson's comments, however, mask the fact that many anthropologists have themselves been critical of the direction taken by native title. But if we take his comments on an 'anthropological conception' to indicate a prescriptive rather than 'open' form of recognition, then they draw our attention to the effects of native title in delimiting and forcefully re-shaping the character of Indigenous ties to traditional lands.

There have also been increasing criticisms of native title from across the political spectrum. The Howard Government has been vehement in its ongoing criticism of native title, arguing both that native title has failed to deliver tangible benefits to Aboriginal people, and that it has significantly impacted economic development, particularly in 'regional' Australia. This continuing governmental critique has also led to practical interventions, most notably the Federal government's '10 point plan', developed in response to the success of the Wik and Wik Way peoples' native title claim in western Cape York Peninsula. More recently, the Howard government has sought to overhaul the native title system to ensure the faster and more efficient processing of native title claims. In so 
doing, the government has inquired into the effectiveness of representative Aboriginal and Torres Strait Islander bodies, the relationship between the Federal Court and the National Native Title Tribunal, the effectiveness of Native Title Tribunal mediation, and the ways in which prescribed bodies corporate operate. On the basis of their continuing criticisms and interventions, it remains unclear to what degree the Howard government wishes to improve the functioning of Australia's native title system and its ability to produce tangible effects, and to what degree the government wishes to further lessen native title's impacts on the status quo.

In this collection, we identify three main effects of native title. Firstly, a number of the papers deal with the issue of recognition - the ways in which the native title process establishes particular groups of Indigenous Australians as (potential) 'native title holders'. As a number of the papers suggest, rather than simply recognising pre-existent social groups and importing wholesale the manner in which traditional law and custom operate in local Indigenous contexts into the 'mainstream' or the 'intercultural' context of native title, the process of 'recognition' is necessarily partial and transformative. The 'effects' of native title thus include the ways in which 'recognition' operates as a particular social and cultural process.

Secondly, several of the papers explore the closely linked theme of translation. Anthropology - deeply embedded, in Australia, in the practice of native title and its social effects - is often spoken of (more or less problematically) as a discipline that specialises in 'cultural translation'. ${ }^{2}$ But translation is never a simple or direct process. For translation to be possible in any simple sense there must be commensurability between the terms of the two systems-linguistic or cultural-between which the act of translation is taking place. In practice, in translating a language - or a set of culturally inflected forms and practices - there is almost always a transformation. This goes largely unrecognised in the native title process, which in some respects can be viewed as an exercise in 'enforced commensurability' (Morphy, Chapter 2, and see Povinelli 2001). A number of the papers in this collection explore the effects of such translation-induced transformations both within the native title process itself (for example, in the courtroom or in the process leading to a consent determination ${ }^{3}$ ) and in the effects that 'flow on' from the native title process (in the existence and practice of codified native title 'rights and interests', and in acts of 'misrecognition', for instance).

2 The anthropological 'translation process' involves the construction of a meta-language in terms of which comparison between two cultural forms can then be framed. Morphy (Chapter 2) distinguishes this process as explication rather than translation.

3 As one of the readers for the ANU E Press notes, the settling of a native title claim by consent and a determination of native title following a full trial involve markedly different processes which will likely lead to different - although not completely distinct - social effects. 
Lastly, this collection explores issues relating to coexistence - the ways that particular individuals, groups and 'peoples' live together. This includes both the coexistence of different Indigenous groups or factions, who may either cooperate with and support or contest claims to native title by other Aboriginal people or Torres Strait Islanders, as well as the coexistence of Indigenous and non-Indigenous or 'settler' Australians. Taken together the papers reveal that the circumstances of coexistence vary considerably from place to place and context to context. More broadly, the papers also consider the implications of coexistence at broader levels - between State and Territory governments and Indigenous populations for example. In all of these instances, coexistence has been deeply affected by the 'native title era', in both positive and negative ways.

\section{Recognition}

$[\mathrm{T}]$ here is a profound irony involved in the idea of recognition: the very desire that makes that ideal so compelling - the desire for sovereign agency, for an antidote to the riskiness and intermittent opacity of social life - may itself help to sustain some of the forms of injustice that many proponents of recognition rightly aim to overcome.

(Patchen Markell, Bound by Recognition, p. 5)

As Manu Barcham (Chapter 11) notes, the last 20 years have seen unprecedented levels of recognition given to the Indigenous peoples of Australia. Citing Fraser's (1995) claim that the politics of recognition has replaced the politics of redistribution in Anglo-American counties, Barcham cautions that recognition involves particular social and cultural transformations which may produce problems as well as benefits for Indigenous people.

These problems of recognition are insightfully identified by the political philosopher Patchen Markell. Markell (2003)—building on Hegel's account of the 'struggle for recognition', and responding to the recent explosion in the politics of recognition-identifies two interrelated grounds for concern about such a politics. Firstly, he suggests that we might take note of a strand of political thought, running from Tocqueville to Arendt, that cautions against the idea that we might be able to achieve certainty in social and political relations. Rather than being problematic, or even pathological, 'uncertainty' may well name an irreducible condition of human life. As several of the authors in this collection note, the desire for certainty has been at the heart of responses to the advent and development of native title. Moreover, it may well be that indeterminacy is even more important within the context of Indigenous cultural production than in other social and political contexts (see Smith 2003b). Even if this is not the case, Markell cautions us against a desire for certainty, through recognition, that may 'blind us to certain ineliminable, and perhaps also valuable, aspects of our own situation' (2003: 4). 
Noel Pearson's (1997) model of the 'recognition space' allows us to explore the operation and the perhaps problematic effects of recognition on the basis of native title in Australia. Pearson's model-from which he has now resiled - presents native title as existing in the overlap between distinct fields of Aboriginal law and Australian law. This model has continued to be touchstone for those seeking to understand this process, in particular through the work of David Martin and Christos Mantziaris (see Mantziaris and Martin 2000; Martin 2004) cited by several of the contributors to this collection.

For Martin, the recognition space also involves a process of translation (see below) and a hegemonic, rather than equal interplay between the two forms of property law that coincide in this space. Further, Martin also notes that the recognition space is only one aspect of a complex series of interconnections between Indigenous and non-Indigenous sociocultural forms (see also Smith, Chapter 6).

In his review of Mantziaris and Martin's (2000) book - which contains their account of the recognition space-Weiner (2003) claims that anthropologists need to be more critical of 'the legalistic appropriation of anthropological and ethnographic methodology' and deal with native title as a 'total social fact' (see also Lahn, Chapter 7) — that is, as a social phenomenon which re-shapes the local and broader social contexts with which it articulates. Martin (2003: 3) has, in turn, replied to Weiner's critique, arguing that his and Mantziaris's use of the 'recognition space' concept, criticised by Weiner as over-simplifying the complex interactions between Indigenous Australians and the wider society within which they are now encompassed, was for the limited purpose of identifying the difference between Aboriginal law and custom, and native title rights and interests that develop through the legal process of recognition. Taken together, Mantziaris and Martin's book and Weiner's critique are both of great use in understanding the processes of recognition operating within the native title process.

Another account of recognition in the native title context is provided by Patton $(1995,2000)$, who presents a critical account of the operation of native title law - that is, of native title as a 'social fact' in Weiner's terms. For Patton, recognition is understood as part of a wider process of reterritorialisation in response to the threatened rupture of the fabric of the settler nation-state in Mabo No.2 and its aftermath. But this process remains ambiguous. While it involves the transformative 'capture' (rather than simply recognition) of Indigenous law by the common law of the settler state, it also bears the potential of a commensurate capture of the state by indigenous law and custom, a 'becoming-indigenous of the common law to the extent that it now protects a property right derived from indigenous law' (Patton 2000: 129, cited in Smith, Chapter 6). 
Of course, many Indigenous claimants recognise these problems. As Morphy (Chapter 2) notes, the Yolngu of North-East Arnhem Land came to see the operation of native title as part of an ongoing process of colonisation, having brought with them to the arena a sense of being 'encapsulated but not colonised'. Morphy argues that this does not involve a state of 'false consciousness' on the part of Yolngu claimants; rather, they recognised the power relations at play in the 'recognition space', but simultaneously problematised the legitimacy of the state's assertions, and insisted on the continuation of other social domains in which their own law and custom remain autonomous from the state, and dominate the construction of social action.

In southern Australia too, Aboriginal people continue to express concerns about the non-Indigenous determination of the character of native title, and the compromises and effects of native title claims. Whilst some of the Aboriginal people of the Murray and Lower Darling Rivers have chosen to pursue native title claims, their recognition of the limited - and increasingly narrow - character of 'recognition' offered by native title has led to the formation of an Indigenous alliance, the Murray Lower Darling Rivers Indigenous Nations (MLDRIN), to pursue more meaningful recognition outside the ambit of the Native Title Act (Weir and Ross, Chapter 10). For the members of MLDRIN, traditional ownership pre-exists and extends far beyond the limited recognition of rights and interests available as 'native title holders'. In negotiating agreements and partnerships outside of the native title framework, MLDRIN's members see themselves as gaining forms of recognition that come far closer to recognising them as 'self-determining' traditional owner groups than would be possible under the NTA, and which do not subject them to 'another colonial validation process'. But MLDRIN's members also see advantages in the native title system. In particular, native title is seen as a means to gain broader recognition of Indigenous rights, despite the risk of a commensurate loss of recognition where claims are unsuccessful.

Although Aboriginal people may recognise the complexities of being party to the native title process, the question of false consciousness, however uncomfortable, cannot be ignored. Many Aboriginal people, for example, continue to understand native title as being bound to continuing Indigenous sovereignty and maintain that they are able to hold a part of their sovereign selfhood at a reserve from their articulations with the state and the 'mainstream'. From the perspective of the courts enacting the native title process however - as Morphy (Chapter 2) rightly notes - sovereignty is not at issue with regard to the NTA. The High Court has already rejected the use of Native Title as 'a vehicle to claim indigenous legal and political sovereignty' (Mantziaris \& Martin 2000: 28). To enter into a native title claim, no matter what reservations are voiced by claimants, is to submit to the state's authority over the contemporary existence of indigenous property rights, even as they exist between Indigenous Australians. 
Whatever its potential 'symbolic' or 'practical' benefits, native title - at least as it exists under the NTA - involves the 'radical enactment of sovereignty' over colonised subjects (see also Lahn, Chapter 7). Further, the ability of Aboriginal people anywhere in Australia to think of themselves in a manner autonomous from the state and the mainstream remains open to question. It seems likely that many, if not all forms of contemporary Indigenous identity are at least inflected by forms of identity making - and the 'politics of recognition' - that are deeply tied to the 'encapsulating' mainstream both nationally and internationally.

From this perspective, Aboriginal claims of autonomy from an encapsulating nation-state seem problematic. As Weir and Ross (Chapter 10) rightly note, it is impossible to unpick the assertions of Indigenous group identity in the Murray-Darling region from the intercultural environment within which it came into being and continues to operate. Whilst it may be true that MLDRIN has a distinct character as a result of having emerged as the result of contemporary Indigenous social action (albeit with roots in ongoing 'custom and tradition'), both the kinds of group identities that coalesce within MLDRIN and the ways it operates as 'traditional owner' organisation are undoubtedly inflected by 'complex historical processes of interaction' between Aboriginal people and settler society (Weir and Ross, Chapter 10, citing Tully 2004). Both the forms of recognition offered to Indigenous Australians and the desire for recognition itself today form part of the intercultural existence of Aboriginal Australians and Torres Strait Islanders in the context of the nation-state (and, beyond Australia, the international context which is often cited by Indigenous Australians as a source of potential recognition beyond the limited forms offered by Australian governments).

One of the most common complaints Aboriginal Australians make about the native title process - itself based in a sense of autonomy and a desire for self-determination - is that native title involves 'Aboriginal people having to prove our right to "them" [i.e., to settler Australians and 'their' legal system]'. From this perspective, native title is again seen not just as a system of recognition, but also as a system of continuing colonial domination-Aboriginal people have to prove their 'rights', whilst settler law not only remains unquestioned, but also retains the authority to rule over the acceptability of Indigenous claims (cf. Morris 2003). Nonetheless, the desire of many Aboriginal people to gain recognition in the eyes of Australian law as 'traditional owners' puts many people in a position in which they must necessarily endure this process and its perceived inequities or questionable authority in order to protect their interests and continue to benefit from their connection to their country.

The authority of the non-Indigenous system of law in the native title context is evident in Morphy's description of the court proceedings in the Blue Mud Bay Native Title Claim (Chapter 2). Morphy notes the existence of elaborate court 
rules which determine who gets to speak, in what way, and at what points. This discursive structure emphasises the authority of the Judge, who can choose to speak freely at any time. But the Yolngu claimants, who are the most knowledgeable about their own system of 'laws and customs', have the most severely curtailed rights to speak in the space of the court. As Morphy notes, the court rules which structure the admissibility (or not) of various kinds of discourse (and of various speakers) 'seems designed ... to emphasise the power of European law by systematically constraining the ability of the knowledgeable practitioners to express that law clearly in its own terms and in its fullness'. The result of these rules is that Yolngu law is 'present, but not enacted' in the court, 'rather, it is explicated through the mediating discourse of examination and cross-examination', which constrain the way in which Yolngu law is represented, forcing it to become merely subsidiary to both the terms and authority of European law.

The authority that inheres in the 'ritual space of the court' is also made evident in other ways. As Pierre Bourdieu has demonstrated, the organisation of particular social spaces is deeply connected to-and reproductive of-socio-religious structures. Like the Kabyle house analysed by Bourdieu (1977), the European courtroom, constructed according to an established set of rules, brings those attending the court into a spatial field saturated by particular cultural orientations. Whilst many such spaces appear as apparently culturally-uninflected or neutral to those whose own selfhood is established in the socio-cultural milieu from which the space is drawn, Morphy's identification of the courtroom as a 'ritual space' makes it clear that its intrinsic meanings are experienced as forceful even by those - the Judge, court officials, lawyers - to whom it is familiar. For other participants - in particular, the Yolngu claimants - the court is alienating not because of a simple cultural disjuncture, but because this disjuncture is one inextricably tied to the ritual performance of power in the person of the Judge and the legal apparatus he or she represents. Thus even before the court makes its authority evident through disciplining speech, this authority is established prima facie by the courtroom itself. As a literal manifestation of the supposed 'recognition space' of native title, the courtroom makes it abundantly clear to all participants - and to Aboriginal claimants in particular - that any such recognition will take place on the basis of particular cultural foundations, and under the authority of the Australian legal system.

As Morphy makes clear, however, although Yolngu claimants were forced to accommodate the court's authority within the native title process, they were also able to make their own system of law visible within the space of the court. Moreover, events that occurred during the court hearings were taken by the Yolngu claimants to be evidence of the power of an autonomous system of ancestral law that continues to inhere in country regardless of the attempts of Australian law to superimpose itself on Yolngu homelands. 
Yolngu claimants successfully endeavoured to make their own law evident in the court through performing a ceremony to 'welcome' the judge and the court. Such performances, of course, continue to be an enactment of the local authority of particular Aboriginal groups. In participating in this ceremony (and a later performance of Yolngu law at Blue Mud Bay itself) the court implicitly acknowledged the ownership and authority of the clans conducting the welcome. Further, as Morphy notes, the ceremony spatially disrupted the court space, displacing most of the court officials and other non-Yolngu. This spatial displacement-notably not including the judge-made further implicit demonstration of the delimited nature of Yolngu claimants' accession to the court's authority.

The court's authority was further undermined, from a Yolngu perspective, by events that occurred during 'site visits' within the claim area. In particular, unusually rough conditions during a boat trip were interpreted by Yolngu claimants as a manifestation of local ancestral beings' displeasure. The evident power of these beings was evidence, for Yolngu, of incommensurability between 'European' and 'Yolngu' law. Whilst the court might insist on its own authority and power to shape the conditions of recognition within its own 'recognition space', the power of Yolngu ancestors made it evident that the court proceedings were unable to affect the ancestral power that underlies the Yolngu law and custom on which the court sought to operate.

The problem is, of course, that the NTA has extended the power of the Australian legal system further into Aboriginal lives. Even for the Yolngu of Blue Mud Bay, the power of local ancestral beings has only been able to translate into restricted intercultural rights with regard to the waters of the claim area. And these rights have themselves been objectified and transformed by the native title process.

The process of recognition entails the objectification, codification and hence reification of certain aspects of cultural practice as property rights under native title. This can lead to tension between the resulting textualised reifications of customary tenure and local Indigenous practice, as is demonstrated in the papers by Claudie (Chapter 5) and Foley (Chapter 9). For Claudie, native title process generates and supports structures that are at odds with local Indigenous land tenure and governance systems despite its supposed basis in recognising 'traditional law and custom'. In central Cape York Peninsula, native title claims lodged on behalf of broader language-named identity groups fail to take sufficient account of local principles assigning primary interests in particular areas to specific families or descent groups, or assigning the right to speak authoritatively to country differentially amongst the people associated with a particular area. Although both native title case law and the complexities of connection arguably make it necessary to be broadly inclusive in determining a claimant group in this region, such broad-based claims then allow for the possibility of the assertion 
of interests by members of the claimant group at odds with local Aboriginal law and custom.

Foley makes similar criticisms in relation to the effects of both the New South Wales Land Rights Act 1983 and the NTA. In Foley's opinion, the New South Wales Act enabled a 'land grab' by local Aboriginal Land councils, often without the involvement or consent of local Aboriginal people. These land councils are perceived as being duplicitous in advertising and organising meetings, and excluding other Aboriginal people, in order to meet the needs of members exercising control over the council. If some land councils have been remiss in serving their constituents or clients, a number of Aboriginal people believe that others may have purposefully manipulated their role for personal benefits.

In the particular case discussed by Foley, the situation is made more complex by the fact that those Aboriginal people controlling the local land council do not identify themselves as traditional owners of areas which they control. Further, they have denied the continuing existence of any traditional owners in some of these areas, despite dealing with people on the basis of their 'custodianship' of these areas in other contexts. Foley argues that the current land council system needs to be revised to include traditional owners or custodians on executive committees, greater transparency in the operation of the land rights system, a land sales register created to protect those Aboriginal people who are not members of the local land council, and a review undertaken of who is able to act authoritatively in 'cultural heritage' matters (such as site clearance in advance of development projects).

In other instances, the dynamics of identification and objectification within the native title process - as well as in 'land rights' legislation-may have less problematic outcomes from the perspective of 'local' claimants. In Chapter 7, Lahn describes the way that native title claims produce new social groupings in response to the terms of the NTA and its interpretations. Lahn describes the situation on the Island of Warraber in the Torres Strait, where there are two contrasting modes of Indigeneity — netiv ('native') and porena ('foreigner').

Although all Warrabeans can trace both native and foreigner forebears, a local emphasis on patrilineal descent means that the majority assert a porena identity. A successful claim under the Torres Strait Islander Land Act 1991 (TSILA) proceeded on the basis of 'customary affiliation'. However, the relatively open definition of key terms in the TSILA allowed recourse to local accounts of Ailan kastom ('Island tradition'), leading to a claim by a 'clan' group whose membership depended on either consanguineal or affinal ties (i.e. 'blood'/'descent' ties or ties through marriage) to families identified with a Vanuatan forbear. The principles of membership allowed for the emergence of an 'inclusive and seamless' claimant group. 
Following TSILA claim, Warraber residents initiated a NT claim. However, as Lahn notes, '[t]he Native Title Act demanded a demonstration of emplaced social identity that was subject to much more sharply delimited terms of authenticity and legitimacy than [in the] TSILA' - in particular by emphasising specific forms of continuity with the colonial past. Lahn, who worked on the ensuing native title claim, notes that despite the superficially straightforward nature of producing a connection report in this context (e.g. identifiable Warraber ancestors present at annexation in 1872), the Warraber native title claim faced a fundamental problem. The laws and norms that shape the native title process 'marginalised and potentially stigmatised' the local principles that underlay the 'clan' identity which provided the focus for the TSILA claimant group. The principal ancestral figure in the previous TSILA claim was not a Torres Strait Islander and had never resided on Warraber, a situation that infringes what have come to be regarded as key requirements for the consent determination of native title in the State of Queensland.

As a result, a new group identity was asserted for the purposes of the native title claim, based on a number of netiv forebears (most of whom were women) and a collective identity as Warraberalgal ('people belonging to Warraber'). This new group accorded with the conditions for successful native title, but did so through departing from the normative local emphasis on male forebears and the established porena forebear-focused Gau Clan identity. As Lahn notes, the Warraberalgal native title claimant grouping marked native title as a realm of intercultural production, where an emergent group (and the linked local process of collective representation) was determined as much by the formal and informal expectations of the state as by continuities in local law and custom.

The contemporary and historical complexities of group identities are often elided in native title claims. This is ironic, given that native title has emerged as a historical context of particular import in the refiguring of local identities and groups. Whilst the need to 'get a claim over the line' is often seen as impeding a critical examination of regional histories of the articulation of Aboriginal identities, the papers in this collection point towards a rich and relatively under-examined aspect of Indigenous Australian life-worlds and their articulation with the Australian 'mainstream'. As the papers here indicate, native title can be the context for the development of new groups, the resurgence of 'undergrounded' Aboriginal identities (Sutton 2003) and the transformation of extant social categories in a changing intercultural context.

Here the effects of native title are shaped by the relatively conservative and limited forms of recognition it offers, forms that nonetheless have radical effects on both the 'content' of native title and the local social fields in which it acts. Like all social milieus - in particular those which have emerged from a recent history of colonialism - the life-worlds of Aboriginal Australians are founded 
in the interplay of received forms of knowledge and action ('traditional law and custom') and historical changes and interactions (see Smith, Chapter 6). However, native title tends to engage poorly with such histories, emphasising what is perceived to be traditional and excluding or rejecting what has been subject to profound historical impacts. One key effect of native title has been to crystallise local distinctions between 'traditional' and 'historical' people on this basis. As a result, a number of Indigenous settlements have experienced increased levels of conflict and stress as families who regard the settlement as their home find that they are being identified as 'second class citizens' in relation to those who identify and have perhaps succeeded in being recognised as 'traditional owners'.

However, as Foley and Claudie's papers suggest, this emphasis on the 'traditional' occurs in particular and limited ways. The 'traditional' recognised within the native title process may be at odds with what local Aboriginal groups or individuals regard as 'proper' law and custom, allowing 'outsiders' or those considered to have little or no traditional authority position themselves as 'traditional owners', and marginalising those who regard themselves as truly authoritative or entitled.

The distinction between tradition and history is also explored in Weiner's paper (Chapter 12), which suggests that the distinction represents an ongoing inability of anthropologists (and of the native title system more generally) to grapple with the relationship between cultural change and continuity as a result of differentiating social structure (or 'tradition') from historical processes and subjective experience. This problem is compounded where Aboriginal people insist on the unchangeability of the Law, a commensurate refusal of a constitutive relationship between culture and history.

Weiner notes that in a number of native title claims, issues of connection have been approached through a separation of accounts of historical occupation and activity on the one hand, and the cosmological reckoning of connection on the other. As he rightly points out, this bifurcate approach handicaps the possibility of presenting the two aspects of Indigenous connections as deeply imbricated in one another. In limiting the anthropologist's (and other 'experts') presentation of the iteration of 'traditional law and custom' through a history of practical engagements with 'country', this approach also limits the possibilities of arguing for the interweaving of change and continuity that likely exist across all of 'Indigenous Australia'. Further, to not link the two, from the perspective of social science 'expertise' is disingenuous - as Weiner notes, the distinction, in social science terms, is 'insupportable and factitious'.

For Weiner, the connections between history and anthropology have become increasingly hard to develop given the increasing acceptance of what he calls 'the project of mythopoeia' or 'memoriology', a blurring of the distinction between myth and history which leads to essentialist constructions of enduring 
cultural identities (see also Smith 2006). He notes the widespread use of oral history in native title claims as an alternative to (often absent) written records of previous Aboriginal social action. As Weiner notes, oral histories are often counterposed to 'objective history', polarising Aboriginal and non-Indigenous positions; proponents of Aboriginal rights simultaneously insist on the lack of difference between oral histories and written histories, equating them simply as equivalent kinds of texts. In insisting that this equivalence should be refused, Weiner does not seek to denigrate oral history. Rather, he draws our attention to the ways in which oral histories are aspects of the cultural constitution of identity. A particular kind of meaning-making that emerges from the interplay of event and human apperception, oral history, like other forms of mythic iteration, can be usefully examined by anthropologists assessing the continuities of law and custom in a particular milieu.

Building from Weiner's argument, it may be that anthropologists working in the field of native title might usefully examine the construction of the claimant group - and the arguments or reasons cited by claimants for this construction - as evidence for particular (and perhaps ongoing) forms of 'customary' practice. Doubtless, the desire evident both amongst anthropologists and other professionals working in the field of native title to present less processual accounts of group-ness limit the acceptability of this approach, providing further evidence of the kinds of bad faith that are evident in native title practice. Such an approach also involves a greater commitment to lengthy ethnographic research, which few NTRBs would be able or willing to support. Nonetheless, as Weiner argues - and as Lahn's case study (Chapter 7) also suggests - a defensible anthropological analysis of 'law and custom' must necessarily take account of the various forms of conjuncture (both between settler and indigenous histories, and between indigenous groups themselves) through which current Indigenous connections to country have been constituted. The problem remains whether such accounts will not open the claimants to challenges that may well lead to a finding of a 'loss of continuity' by courts that are less able or willing to accept such accounts of connection.

This ability of the courts to determine the extinguishment of native title is a major concern of native title practitioners, whether such extinguishment occurs on the basis of radical transformation of local Aboriginal law and custom or the development of settler property rights in a given area (in particular the granting of freehold tenure). As Lahn notes, rather than recognition per se, native title's principal effect may be the delimitation of Indigenous relations to land, or the endorsement of claims of extinguishment (see also Morris 2003). Further, as Wolfe (1999: 202) argues, the forms of 'repressive authenticity' demanded by native title displace the burden of historical extinguishment from the expropriating agency of the state to the character of the claimant group. 
The outcome of the Yorta Yorta claim looms large in the native title landscape as the paradigmatic determination of the historical extinguishment of native title. In the Yorta Yorta claim Olney J found that the 'tide of history' had washed away any substantial continuity in law and custom among the claimants and their forebears (see Weir and Ross, Chapter 10). ${ }^{4}$ The Yorta Yorta case made it clear that Aboriginal claimants - in particular those in the 'settled south' of Australia - would be subject to extremely conservative and limited grounds for recognition of their law and custom, although the recent finding in the Noongar case makes it clear that, in some cases at least, native title is able to be recognised in the 'south', albeit in extremely limited forms.

Following Yorta Yorta it has become evident that native title, as it exists under the Native Title Act, may be at odds with a continuing local system of Aboriginal law and custom pertaining to a particular area. Scambary (Chapter 8) notes that the Larrakia people of Darwin, like the Yorta Yorta, have been unable to gain legal recognition of native title rights and interests despite the court's recognition of the Larrakia community as 'a vibrant, dynamic society which embraces its history and traditions'. In the Larrakia claim, the effects of the settlement of Darwin, the arrival of other Aboriginal people into the area and the impacts of government policy proved enough for Mansfield $\mathrm{J}$ to find that the claimants had failed to maintain the required form of traditional and cultural continuity. As Scambary notes, this decision seemingly demonstrates the inability of the NTA to recognise a 'vibrant' society, with clear connections to its history and customs as native title holders.

Like the Warraber claim described by Lahn, the Larrakia native title claim was preceded by a land rights claim (under the Northern Territory's Aboriginal Land Rights Act (ALRA)), which led to the coalescence of a particular named group asserting customary ownership of the land in question. Unlike the TSILA claim, however, the Kenbi ALRA claim fed into the production of a series of disjunct, competing groups asserting traditional rights over parts of the wider Darwin region. Competition between Larrakia factions included the establishment of separate corporations and public contestation at opening ceremonies of other Larrakia groups' credentials. The establishment of an umbrella organisation - the Larrakia Nation Aboriginal Corporation - intended to provide a corporate identity for Larrakia factions also had the unintended result of supporting Mansfield J's determination of extinguishment, being cited as evidence for the radical transformation of traditional decision-making processes.

Dissatisfaction with the limits of recognition of customary land tenure and other aspects of Indigenous Australians' connections to their country have led an

\footnotetext{
4 As one of the referees for the ANU E Press notes, although the Yorta Yorta case has become the focus for much discussion of the 'tide of history' in relation to native title, the more recent Larrakia and Wongatha judgements have led to further developments on this issue.
} 
increasing number to seek alternatives to the native title system. ${ }^{5}$ In central Cape York Peninsula, for instance, Kaanju people's dissatisfaction with native title-discussed in Claudie's paper (Chapter 5) - has led to alternative strategies for the recognition of Kaanju aspirations for land management. In particular, Kaanju people have developed a proposal for an Indigenous Protected Area (IPA) under Federal environmental legislation, which they have used as the basis for partnerships with various governmental, non-governmental and private sector organisations to gain recognition of their indigenous system of governance and management (see Smith and Claudie 2003). The Yolngu are also following this course, with the recent declaration of stage 1 of the Laynhapuy IPA in the Blue Mud Bay area. Similarly, members of several Aboriginal traditional owner groups from the Murray and Lower Darling Rivers in south-eastern Australia, as well as the Wotjobaluk of the Wimemera-Mallee country (see below), ${ }^{6}$ have negotiated agreements with the Victorian government and other 'mainstream' agencies outside of the NTA. In the case of the Murray and Lower Darling Rivers groups, this course of action has been taken partly in response to the failure of the Yorta Yorta people (who are one of the Indigenous 'nations' on the Murray River system) to have native title rights and interests recognised (see Weir and Ross, Chapter 10). All of these cases demonstrate an increasing desire of Aboriginal groups (and government agencies) to circumvent the NTA and find other routes to developing meaningful and substantial forms of recognition of traditional ownership that lead to tangible social, economic and environmental outcomes.

In many cases, the 'business' of recognition may be impeded by the complex dealings between parties representing Aboriginal claimants and other stakeholders in the native title process. Claudie (Chapter 5) outlines perceived failings by a regional land council, which was seen to be responsive rather than proactive in its engagements with the State government. As Claudie points out, these frustrations are (in part, at least) explicable as the result of limited resources and staff, such that land councils are unable to progress all but the most pressing matters at any given time. Even where the reasons for such delays are explained to claimants (and this is not always the case), they do little to persuade Aboriginal people that they are being well served by the native title process.

Doubtless it is these kinds of complexities, in addition to the limited outcomes available in most (although not all) cases, the unpredictable outcomes of court decisions, the lengthy negotiations that may eventually lead to a consent

\footnotetext{
5 Although they are a part of the native title system, Indigenous Land Use Agreements (ILUAs) have also become increasingly important as an alternative means of addressing the limited ability of a determination of native title to meet the aspirations of 'traditional owners' and other parties across Australia.

6 In the November 2005 workshop, where earlier versions of the papers collected here were presented, members of the Wotjobaluk people, in collaboration with employees of State government agencies, described the outcomes they have managed to negotiate beyond the determination of native title. Unfortunately this paper (Beer et al. 2005) was not able to be included in the present collection.
} 
determination, and the kinds of intra-Indigenous and local conflicts that develop in the native title context which have led to the seeking of alternative routes for recognition of indigenous ties to land. Nonetheless, it is unclear how many of these alternatives would be available without the pressure exerted on other partiers by native title claims. In any case, it is clear that we are now dealing with a complex and evolving system of recognition, within which Aboriginal people and Torres Strait Islanders are increasing their ties with 'mainstream' agencies and organisations - and the rest of Australian society - whilst retaining distinct identities as members of particular Indigenous groups.

\section{Translation}

Any translation inherently compromises the original

(John McWhorter, The Power of Babel, p. 38)

Translation is a key element of the native title process. As Mantziaris and Martin note, "native title involves a process of translation from indigenous "relations" defined by traditional law and custom to native title rights and interests enforceable within the Australian legal system. This process of translation becomes difficult, or impossible, when the terms of the translation are incommensurable' (2000: 29; see also Morphy, Chapter 2).

The linked issues of translation and incommensurability are deeply imbricated in the effects of native title. Whilst such incommensurability is neither inevitable nor uncircumventable, several of the papers in this collection suggest that translation and incommensurability do present problems in the context of native title processes, and that these problems are compounded by the force and authority brought to bear by the native title system, to the benefit of some parties and the detriment of others. Povinelli (2001) draws attention to the issue of power relations in determining 'linguistic distortion (commensurability and incommensurability)', citing Asad's comment that insofar as 'the languages of the Third World societies ... are "weaker" in relation to Western languages ... they are more likely to submit to forcible transformation in the translation process than the other way round' (Asad 1986: 157-8, cited in Povinelli 2001: 324). In the native title context, it is Indigenous terms and social forms that are required to submit to transformation, in a process that Morphy (Chapter 2) terms 'enforced commensurability'. The Yolngu 'insistence on difference' can be seen as a form of rhetorical resistance to this process.

Lahn's case study (Chapter 7) provides a clear example of forcible transformation. The English-based Torres Strait Creole terms 'neitiv' and 'porena' both reference types of indigeneity acknowledged by Torres Strait Islanders, but 'this situation is a difficult one to render in English, which lacks adequate means to characterise such a contrast in a way that still affirms an embracing state of indigeneity'. English's problem is turned back onto the Warraberan native title applicants, 
who had previously pursued a successful land claim under the TSILA under a collective representation, the Gau clan, which stressed patrilineal descent from porena ancestors. In their native title case, in the context of a regime which 'marginalised and potentially stigmatised' porena indigeneity, the applicants were forced to adopt an alternative form of collective representation as Warraberalgal 'people belonging to Warraber' who traced descent primarily through neitiv female ancestors.

Another example of the problems of 'translation' in the context of native title is provided by Morphy (Chapter 2) in her analysis of the workings of the court in the Blue Mud Bay Native Title claim. In the Blue Mud Bay case, the court's hearing of evidence relied partly on 'witness statements', prepared statements that are intended to assist the court by reducing the amount of time taken up by hearing evidence, ensuring the applicants' case is well-articulated and allowing other parties time to consider their response. Morphy — who acted as an expert assisting the court in this case - discusses her concerns that the written form of such statements potentially disadvantaged Aboriginal witnesses. The perceived disadvantage lay with potential problems of understanding and translation. In the Blue Mud Bay case, Selway J was not inclined to take such claims into consideration, noting the intelligence and relative sophistication [with regard to the workings of European society]' demonstrated by most of the Yolngu witnesses. Nonetheless he did note 'potential issues arising from translation between Yolngu language and English'.

Morphy argues that, rather than simply 'translation', the preparation of witness statements involves a complex process in which a Yolngu concept, which may have no direct equivalent in English, is presented in the context of an English statement. This statement is later glossed by Land Council lawyers (in the form of an affidavit), replacing the terms in Yolngu-matha with what are taken to be commensurate terms in English. This affidavit is, in turn, presented back to the witness, often with a translator present, and sworn as his or her own statement. Unfortunately two key presumptions in this process - that there are simple equivalents for words/concepts drawn from one language in another language, and that the words use to gloss Yolngu terms have the same meaning for the witness and for the court - do not hold. Rather, the process of replacing a term in Yolngu-matha with an English term obscures the particular meaning of the Yolngu term within its own cultural context. Further, the use of number English terms in the legal context (e.g. 'permission') in witness statements commit the Yolngu witness to legal claims whose particular meanings are invisible to the witness and potentially at variance with the claims they were trying to make in their original statement. This can present particular problems when witnesses are cross-examined on the contents of 'their' statements, which can lead to apparent differences or contradictions between the witness's response and 'their' earlier statement, potentially undermining their case. Alternatively, the potential 
disjuncture between the language of a witness statement and the witness's oral evidence can also be used to cast doubt on the provenance of the written statement, and its admissibility as evidence in the proceedings.

Markell argues that a politics of recognition - including one based on notions of difference - may lead to the continuation or extension of deep-seated relations of inequality and power (2003: 4-5). In situations of cultural difference, the inequalities effected by 'recognition' may include forms of misrecognition that although superficially cognisant of (or based on) difference, in fact manifest ethnocentric and transformative engagements with disempowered groups. It could be argued that the source of this misrecognition in Australian native title is the insistence on translatability through a process of enforced commensurability. Several of the papers in this collection suggest that misrecognition of this kind is, indeed, common in the native title context, a suggestion likely to cause some discomfort for those anthropologists-among others - who have seen involvement in native title claims as a means to further social justice in relation to Indigenous Australians.

In Chapter 3, Glaskin examines the transformative impacts of native title, drawing on her research with Bardi and Jawi people in the northwest Kimberley. For Glaskin, native title does not simply recognise, but rather codifies Aboriginal property rights. Indeed, the native title process demands that claimants themselves articulate and objectify aspects of their property relations. These include aspects of Aboriginal cultural practice that are normatively implicit, and Glaskin argues that the discursive reification of these aspects of cultural practice, and the ensuing 'dialectics of articulation', will likely have considerable impact on the social lives of Bardi and Jawi claimants.

Following Wagner (1981[1975]), Glaskin suggests that any 'self-conscious' articulation of 'culture' will be constrained by the strictures of identity. In the case of native title claims, self-conscious definitions may well 'feed back' into the identities of native title holders in the manner identified by Hirsch (2001) as the 'looping effect of human kinds', which occurs 'especially where such objectification becomes reified or codified in some form'. Whilst Bardi and Jawi people have long reified aspects of their law and culture - in particular in ritual or religious knowledge and practice - the forms of reification involved in native title claims are likely to have very different effects to these indigenous practices of reification. Detached from the field of the 'inner workings' of Bardi and Jawi society, the intercultural or 'conjunctural' field of native title demands forms of reification alien to local practices of cultural production. In particular, the composition of a prescribed body corporate, a necessity following a successful native title claim, meant that Bardi and Jawi people found themselves attempting to objectify their traditional cultural principles or 'rules' to shape the workings of the new corporation. Glaskin notes that the codification of principles and 
processes within portions of the draft constitution represented a transition from the previously informal and negotiative enactment of the local Aboriginal jural public. The native title process is leading to an explicit formulation of the principles of customary law. This textual codification seems likely to 'transform 'social values and practices' by freezing these at a given point in time and thereby 'encouraging stasis in the system', with the system itself likely to 'dialectically evolve with reference to these representations' (Glaskin, Chapter 3, citing Mantziaris and Martin 2000: 43; see also Smith 2003b). Moreover, this process of textualisation may potentially lead the resolution of questions of interpretation of local laws and customs - questions whose articulation lies at the heart of the enactment of Aboriginal 'law' - to be taken over to a greater or lesser extent by outside experts, including lawyers and anthropologists.

Glaskin suggests that the articulation of textualised reifications of Aboriginal law and custom may also lead to increased conflict between Aboriginal groups or factions. Similarly, Barcham (Chapter 11) suggests that the 'neo-traditional corporate constructs' that emerged in response to recent policies regarding Māori property and resource rights led to a number of acrimonious court battles between iwi ('tribal') groups and representatives of urban Māori. Like Glaskin, Barcham suggests that the articulation between 'frozen' or reified versions of Indigenous society and the ongoing iterations of local Indigenous practice may become increasingly problematic.

\section{Coexistence}

[N]ot being able to say 'we' is what plunges every ' $\mathrm{I}$, ' whether individual or collective, into the insanity where he cannot say ' $I$ ' either. To want to say 'we' is not at all sentimental, not at all familial or 'communitarian.' It is existence reclaiming its due or its condition: coexistence.

(Jean-Luc Nancy, Being Singular Plural, p. 42)

One of the most important social effects of native title has been its impact on coexistence. Since the initial success of the Mabo No. 2 claim and the passing of the NTA, native title has been labelled as a threat to co-existence. Such claims are exemplified by the statements made following the passage of the Act by the then Deputy Prime Minister Tim Fischer's about the threat to Australians' backyards (claims echoed in the Attorney-General Philip Ruddock's recent claims that the Noongar native title case in Perth represents a threat to beaches and parks around Australia).

In Chapter 6, Smith discusses the relationship between Aboriginal people and pastoralists in central Cape York Peninsula, at the eastern fringes of the Wik claim area. Until recently, these relationships have remained extremely close, but also deeply marked by the history of indentured labour relationships between Aborigines and settlers. But a decline in Aboriginal employment following the 
'freedom' of the 1970s has weakened - although not removed - these ties, which were further strained by the advent of land rights and the NTA). Non-Indigenous pastoralists' responses to the Wik claim were initially extremely negative, and many claimed that the recognition of native title rights and interests in the area of their pastoral leases would bankrupt them. However, following the Howard government's 10-point plan and a growing understanding of the practical effects of native title, many (although not all) of the region's pastoralists became more willing to negotiate ILUAs and support a determination of limited native title rights in their lease areas. In so doing, a number of the pastoralists publicly asserted their desire to re-develop ties with local Aboriginal families, whilst also stressing their need for control of activities in their lease areas and their desire for privacy.

This mixture of solicitation of social relationships and assertion of the need for control and privacy is at least superficially reminiscent of the now widely-recognised dynamic between autonomy and relatedness that lies at the heart of Aboriginal social relations (Martin 1993; Myers 1986). Certainly the pastoralists' asserted needs were recognised by the Aborigines with whom they were negotiating proposed ILUAs - not least because most of the Aborigines were themselves familiar with the requirements of running a cattle station. But Smith argues that there are more than superficial parallels or particular historical ties at play in such situations. Rather, the intercultural space of negotiation between Aborigines and settlers in remote Australia itself subsists within a more general human orientation to relations with and between other persons. Perhaps the most successful approach made by the settlers in the context of the ILUA negotiations was an emphasis on face-to-face and informal negotiation of ongoing coexistence rather than on formal legal structures. This inter-personal emphasis resonates strongly with the indeterminate or 'uncertain' but heavily interactive character of local Aboriginal sociality in a manner that reassured the Aboriginal claimants that a meaningful social outcome was possible as part of the agreement-making process. Nonetheless, there was some ingenuousness to the pastoralists' claims - their insistence on informal relations took place against the backdrop of a formal agreement that they were assured allowed them near-absolute control over when and where Aborigines could make use of country within their leases. And it seems certain that there would have been no such negotiations unless the NTA had impelled the settlers to 'come to the table' in the first place. Thus whilst meaningful 'informal' coexistence (and, arguably, a measure of social justice) may yet emerge from the Wik decision, it has taken the formal force of the law to bring this about.

Redmond's paper (Chapter 4) similarly addresses the topic of 'pathways out of the near-hegemonic relations of the past' in the context of the native title process. In the Northern Kimberley, the suppressed memories of historical oppression of Aboriginal people by European pastoralists were laid bare in the adversarial 
process of the pursuit of native title. Nonetheless, as in central Cape York Peninsula, Aboriginal and non-Indigenous parties in the native title process were both required to and in many cases remain desirous of continuing to co-exist in the region.

Like Morphy (Chapter 2), Redmond focuses on the courtroom as the social context within which competing constructions of Aboriginal connections were articulated. In the case of the Ngarinyin peoples' claim, however, the contestation of continuing Aboriginal title included counter-claims made by a number of local pastoralists, many of whom have long-standing social connections with Ngarinyin people. These pastoralists included both an 'elite' contingent, and other pastoralists who represented themselves as 'battlers'. With regard to both sets of pastoralists, the native title claim saw a worsening of social relationships with the Aboriginal claimants. The perceived threat of native title to the pastoralists' interests led to an aggressive challenge to the Ngarinyin claim, accompanied by attempts to exclude claimants from cattle stations, even after a successful determination of native title rights and interests in the areas covered by the pastoralists' leases. The pastoralists were also aggrieved by the manner in which the court proceedings elicited frank accounts of the mistreatment of Aboriginal workers and their families by their white 'bosses', despite Aboriginal attempts to accompany such accounts with reference to the close ties that have continued to exist between the Ngarinyin and their employers.

Despite the context of the courtroom - which, as Redmond notes, might have proved overwhelming for the claimants, given that for most of them it had only ever been experienced as a place of punishment-and the attempts by the respondents' lawyers to trip up and shame the Ngarinyin in cross-examination, the claimants' resilience led to a determination of extensive (and in some cases exclusive) determination of native title. However, the effects of the determination with regard to regional coexistence have been ambiguous. On the one hand, Redmond suggests that native title 'may well open up pathways out of the almost hegemonic relationships of the past'. Further, at least some pastoralists have begun to rekindle relationships with select groups among the claimants. On the other hand, locked gates, the establishment of access protocols which (consciously or otherwise) act to further exclude the Ngarinyin from their homelands, and other forms of resistance to the claimants' win mean that many Ngarinyin feel that little or nothing has changed following the determination.

The hardening of non-Indigenous attitudes to Aboriginal groups in response to claims over traditional homelands is apparently widespread. Scambary (Chapter 8) describes the ongoing politicisation of Indigenous rights in the Northern Territory, where reactionary statements about land rights and native title have proved to be sure-fire vote winners. The Larrakia claim over Darwin has been the target of reactionary politics by both the Country Liberal and Labor parties 
in the Territory, as well as of a broader public backlash that followed the 1996 lodgement of Darwin area claim. This backlash focused both on fears that the wider public would be excluded from areas such as public beaches and reserves (despite assurances by claimants that they did not seek to exclude non-Larrakia) and fears over hindrances to development. Notably both sets of fears have again surfaced in reaction to the recent successful claim by the Noongar people over the Perth area. ${ }^{7}$

Scambary's paper points to the complexities of co-existence in relation to native title, which affects relationships not only between Aborigines and settlers but also between claimants and other Aboriginal people. With regard to relations with non-indigenes, Scambary outlines the ways in which the Northern Territory government simultaneously opposed the Larrakia Native Title Claim and sought the involvement of the Larrakia Nation in the 'Community Harmony' project, which sought to address the issue of Aboriginal itinerants in Darwin, in part through the development of protocol for Aboriginal people visiting Darwin.

Indigenous 'itinerants', for the most part, have developed fairly good relations with the Larrakia, and many itinerants supported the Larrakia claim. However, Scambary suggests that the relationship between the Larrakia and the itinerants was weakened by the native title process. The native title claim was cited by the Northern Territory government as preventing the grant of title to an established fringe camp area (despite successfully negotiated deals for land use between the Larrakia and non-Indigenous parties) and the ability of the Larrakia to support itinerant interests was weakened by the demands of the native title process. As a result, ties between the Larrakia and itinerant groups became strained. Further, the partnerships that had developed between the Larrakia and the Territory government were wound back when the government decided to retreat from these partnership arrangements in order to bolster support for an upcoming election.

In other cases, a more positive relationship seems to have developed between governments and local Indigenous groups in the native title context. In Victoria, for example, the Wotjobaluk people, despite some reservations, have established successful partnerships with the Victorian Government following the registration and eventual consent determination of a native title claim (Beer et. al. 2005). Building on a government policy of recognition of traditional owners within and beyond the parameters of native title, these partnerships have involved a number of developments that have gone a considerable way to meeting the aspirations of the Wotjobaluk group. These include social and economic

\footnotetext{
${ }^{7}$ It should be noted, however, that on this occasion those politicians opposing the determination appear to have been wrong-footed by the general public of Perth, many of whom welcomed the native title decision, a reaction that further confirms the potential of native title to act as a vehicle for reconciliation between Indigenous and settler Australians.
} 
aspirations (e.g. the preservation of 'oral history' and cultural knowledge, and the development of a financial base for Wotjobaluk activities), partnerships in the management of Wotjobaluk traditional country (including employment in land management and advisory roles and ownership of significant pieces of land), and the recognition of the Wotjobaluk as traditional owners. From the perspective of the Victorian government, it has been important to establish a framework for the acknowledgement of traditional ownership and to seek to resolve conflicts between and within native title and traditional owner groups. Through the development of relationships with these groups it is also clear that the State government has sought to use the native title process as a springboard to facilitate social and economic development for the State's Indigenous people.

Unfortunately, other claimants have not had such a positive experience of dealings with State governments. Claudie (Chapter 5) expresses considerable frustration with regard to the State's actions in a claim over his family's traditional homelands in central Cape York Peninsula. After expending considerable effort to produce a report on Aboriginal aspirations for the claim area, the claimants were left waiting while an opaque 'land evaluation' process was undertaken by the State government. This process was further complicated by mixed messages about the State's willingness to concede the continuing existence of native title over the claim area. And the report - when finally sighted by the claimants - persuaded at least some claimants that the State, rather than being prepared to negotiate in good faith, had already decided how it would deal with the area and was simply seeking to justify this decision through a report of possibly dubious quality despite the demonstrated willingness of the traditional owners to reach a compromise that included the interests of all stakeholders.

In sum, it is clear that the relationship between native title and coexistence is a complex one. On the one hand, the recent reaction to the success of the Noongar claim makes it clear that governmental opposition - and public outcry and misinformation - remain strong in the face of native title claims. And reactions to claims in rural and remote areas give lie to the claim that such opposition is due to the urban setting of the Noongar (and similar) claims. On the other hand, some State governments and other parties-including a number of pastoralists - have developed more accommodating perspectives on native title claims, and have also sought to develop forms of meaningful coexistence which extend beyond the confines of native title rights and interests. Doubtless these agreements are partly based on the levels of 'certainty' that have followed from the Federal government's legislative intervention following the success of the Wik claim in the High Court - and it should be remembered that such 'certainty' does not apply to Indigenous groups whose ability to gain meaningful coexistence on their terms have suffered as a result. But current developments within and 
beyond native title nonetheless hold some hope for meaningful steps towards coexistence across Australia.

\section{Conclusion}

The papers in this collection reflect on the various social effects of native title. In particular, the authors consider the ways in which the implementation of the Native Title Act 1993 (Cwlth) - and the native title process for which this act legislates - allows for the recognition and translation of Aboriginal law and custom, and facilitates particular kinds of coexistence between Aboriginal title holders and other Australians. In so doing, the authors seek to extend the debate on native title beyond questions of practice and towards an improved understanding of the effects of native title on the social lives of Indigenous Australians and on Australian society more generally.

These attempts to grapple with the effects of native title have, in part, been impelled by Indigenous people's complaints about the NTA and the native title process. Since the Act was passed, many Indigenous Australians have become increasingly unhappy with both the strength and forms of recognition afforded to traditional law and custom under this Act, as well as the socially disruptive effects of the native title process. In particular - as several of the papers in this collection demonstrate - there is widespread discomfort with the transformative effects of recognition within the native title process, effects which can then 'feed back' into other aspects of Indigenous lives.

It seems clear that many of these problems have been compounded by the treatment of native title as 'a creature of the Native Title Act', rather than continuing to treat native title as the common law recognition of Indigenous law and custom. The resulting juridification of native title (Mantziaris and Martin 2000) has increased the degree of transformation that occurs through the process of 'recognition' of native title. This transformative 'violence' of translation occurs not only within the space of the court, but is also apparent in the approach taken by many NTRBs and anthropologists producing materials accounting for the ongoing connection and custom of claim groups. Such materials are often produced in anticipation of the expectations of other parties - in particular, the State and Federal government agencies charged with 'signing off' on consent determinations of native title, or of the judges ruling on native title claims which are decided in the courts. This effect of the native title process has led to one of native title's greatest ironies - in many cases, strong continuities in Indigenous cultural production hamper 'recognition' of native title due to their lack of fit with the NTA, whilst other groups - among whom cultural continuity has been accompanied by the local production of groups and assertions of rights which better 'fit' expectations based on the Native Title Act - find 'recognition' of their rights and interests proceeds more smoothly on this basis. 
For the latter groups - those characterised by ongoing connection to 'country' and continuities in cultural production, but also by transformations in the articulation of Indigenous identities and property rights as a result of colonial disruption-native title has, on balance, proved to be a positive social phenomenon, allowing the recognition of Indigenous identity and practical benefits to a number of groups. Elsewhere, some Indigenous histories of strong cultural continuity and connection to land - in conjunction with relatively weak forms of colonial tenure - have allowed for the eventual recognition of substantial property rights, even the recognition of exclusive rights in land. But those who fall somewhere between these two positions can find native title particularly frustrating, leading to disappointing practical benefits and forms of recognition that are understood to be profoundly disjunct from those which operate in local social lives. And of course - the Noongar case notwithstanding - many Aboriginal people in more settled areas continue to be frustrated by a lack of recognition of their continuing connections to country and the legal determination of the extinguishment of their rights and interests.

Despite these frustrations and limitations, the papers in this collection suggest that the 'native title era' continues to produce positive results for many (although not all) Indigenous Australians, as well as many settler Australians, and arguably for Australian society as a whole. Positive forms of recognition and coexistence have developed not only within the native title process, but also because of its perceived limitations. A range of alternative provisions now mark the determination of Indigenous Australians to redefine their place in Australian society on the basis of their connections to 'country' even where the NTA has provided little or no recognition of these connections. The Act's provision for the production of Indigenous Land Use Agreements without the formal determination of Native Title, the Indigenous Protected Areas scheme, and a range of alternative processes and agreements (including those developed by the Victorian government, and those relationships developed with Indigenous groups in relation to the Murray-Darling system) all mark an increasing willingness by government departments and other public and private bodies to reach arrangements with Indigenous groups which exceed the recognition afforded by the NTA. In retrospect, the development of such alternatives - one more 'effect' of native title, albeit an effect triggered by its limitations - may prove to be just as important as the more positive effects of the native title process both for Indigenous Australians and their settler neighbours. 


\section{References}

Asad, T. 1986. 'The concept of cultural translation in British social anthropology', in J. Clifford and G. E. Marcus (eds), Writing Culture: The Poetics and Politics of Ethnography, University of California Press, Berkeley.

Bauman, T. 2005. 'Whose benefits? Whose rights? Negotiating rights and interests amongst native title parties,' Land, Rights, Laws: Issues of Native Title, 3 (2), Native Title Research Unit, Australian Institute of Aboriginal and Torres Strait Islander Studies, Canberra.

Bauman, T. 2006a. 'Nations and tribes "within": emerging Aboriginal "nationalisms" in Katherine', in P. Sullivan, and T. Bauman (eds), Delimiting Indigenous Cultures: Conceptual and Spatial Boundaries, Special Issue, The Australian Journal of Anthropology, 17 (3): 322-35.

Bauman, T. 2006b. 'Waiting for Mary: process and practice issues in negotiating native title Indigenous decision-making and dispute management frameworks', Land, Rights, Laws: Issues of Native Title, 3 (6), Native Title Research Unit, Australian Institute of Aboriginal and Torres Strait Islander Studies, Canberra.

Bauman, T. and Williams. R. 2005. The Business of Process: Research Issues in Managing Indigenous Decision Making and Disputes In Land, Report No. 1, Indigenous Facilitation and Mediation Project, Native Title Research Unit, Australian Institute of Aboriginal and Torres Strait Islander Studies, Canberra.

Beer, J., Dalgleish, E., Kennedy, P., Leigh, C. and McLachlan, L. 2005. 'Beyond native title in the Wimmera: the Wotjobaluk, the State and the importance of "doing it local"", paper presented at the workshop Effects of Native Title, convened by B. R. Smith and F. Morphy, Old Canberra House, The Australian National University, 1-2 November.

Berndt, R. and Berndt, C. 1984. Collection of Essays on Aboriginal Land Rights for the Guidance of the Government of Western Australia Aboriginal Land Inquiry 1983-1984, Special Issue, Anthropological Forum, 5(3).

Bourdieu, P. 1977. Outline of a Theory of Practice (trans. Richard Nice), Cambridge University Press, Cambridge.

Correy, S. 2006. 'The reconstitution of Aboriginal sociality through the identification of traditional owners in NSW', in P. Sullivan, and T. Bauman (eds), Delimiting Indigenous Cultures: Conceptual and Spatial Boundaries, Special Issue, The Australian Journal of Anthropology, 17 (3): 336-47.

Fraser, N. 1995. 'From redistribution to recognition? Dilemmas of justice in a 'postsocialist' age', New Left Review, 212 (July/August): 68-93. 
Hiatt, L. 1984. Aboriginal Landowners: Contemporary Issues in the Determination of Traditional Aboriginal Land Ownership, Oceania Monograph No.27, University of Sydney, Sydney.

Hirsch, E. 2001. 'Making up people in Papua', Journal of the Royal Anthropological Institute, 7: 241-56.

Langton, M., Mazel, O. and Palmer, L. 2006. "The "spirit" of the thing: the boundaries of Aboriginal economic relations at Australian common law', in P. Sullivan, and T. Bauman (eds), Delimiting Indigenous Cultures: Conceptual and Spatial Boundaries, Special Issue, The Australian Journal of Anthropology, 17 (3): 307-21.

McWhorter, J. 2002. The Power of Babel, William Heinemann, London.

Mantziaris, C. and Martin, D. F. 2000. Native Title Corporations: A Legal and Anthropological Analysis, Federation Press, Sydney.

Markell, P. 2003. Bound by Recognition, Princeton University Press, Princeton.

Martin, D. F. 1993. Autonomy and Relatedness: An Ethnography of the Wik People of Western Cape York Peninsula, PhD Thesis, The Australian National University, Canberra.

Martin, D. F. 2003. 'Rethinking the design of Indigenous organisations: the need for strategic engagement', CAEPR Discussion Paper No. 248, Centre for Aboriginal Economic Policy Research, The Australian National University, Canberra.

Martin, D. F. 2004. 'Designing institutions in the "recognition space" of native title', In S. Toussaint (ed.), Crossing Boundaries: Cultural, Legal, Historical and Practice Issues in Native Title, Melbourne University Press, Melbourne.

Merlan, F. 1998. Caging The Rainbow: Places, Politics, and Aborigines in a North Australian Town, University of Hawai'i Press, Honolulu.

Morphy, H. and Morphy, F. 2001. 'The spirit of the plains kangaroo', in T. Bonyhady and T. Griffiths (eds), Words for Country: Landscape and Language in Australia, University of New South Wales Press, Sydney.

Morris, B. 2003. 'Anthropology and the state: the ties that bind', in B. Morris and R. Bastin (eds), Expert Knowledge: First World Peoples, Consultancy, and Anthropology, Special Issue, Social Analysis 47 (1): 137-44.

Myers, F. 1986. Pintupi Country, Pintupi Self: Sentiment, Place, and Politics among Western Desert Aborigines, University of California Press, Berkeley.

Nancy, J.-L. 2000. Being Singular Plural, Stanford University Press, Stanford. 
Patton, P. 1995. 'Post-structuralism and the Mabo debate: difference, society and justice', in M. Wilson and A. Yeatman (eds), Justice and Identity: Antipodean Practices, Allen and Unwin, Sydney.

Patton, P. 2000. Deleuze and the Political, Routledge, London.

Pearson, N. 1997. 'The concept of native title at common law', in G. Yunupingu (ed.), Our Land is Our Life, University of Queensland Press, St Lucia.

Pearson, N. 2002, 'Native title's days in the sun are over', The Age (Melbourne), 28 August 2002.

Povinelli, E. 2001. 'Radical worlds: the anthropology of incommensurability and inconceivability', The Annual Review of Anthropology, 30: 319-34.

Povinelli, E. 2002. The Cunning of Recognition: Indigenous Alterity and the Making of Australian Multiculturalism, Duke University Press, Durham.

Rumsey, A. 1989. 'Language groups in Australian Aboriginal land claims', Anthropological Forum, 6 (1): 69-79.

Smith, B. 2003a. "“All been washed away now": tradition, change and Indigenous knowledge in a Queensland Aboriginal land claim', in J. Pottier, A. Bicker and P. Sillitoe (eds), Negotiating Local Knowledge: Power and Identity in Development, Pluto Press, London.

Smith, B. 2003b. 'Whither "certainty"? Coexistence, change and some repercussions of native title in northern Queensland', Anthropological Forum, 13 (1): 27-48.

Smith, B. 2006. "'More than love": locality and affects of Indigeneity in northern Queensland', The Asia-Pacific Journal of Anthropology, 7 (3): 221-35.

Smith, B. R. and Claudie, D. 2003. 'Developing a land and resource management framework for Kaanju Homelands, central Cape York: opportunities and challenges', CAEPR Discussion Paper No. 258, Centre for Aboriginal Economic Policy Research, The Australian National University, Canberra.

Sullivan, P. and Bauman, T. (eds) 2006. Delimiting Indigenous Cultures: Conceptual and Spatial Boundaries, Special Issue, The Australian Journal of Anthropology, 17(3).

Sutton, P. 2003. Native Title in Australia: An Ethnographic Perspective, Cambridge University Press, Cambridge.

Toussaint, S. 2004. Crossing Boundaries: Cultural, Legal, Historical and Practice Issues in Native Title, Melbourne University Press, Melbourne.

Wagner, R. 1981[1975]. The Invention of Culture, University of Chicago Press, Chicago. 
Weiner, J. F. 2003. 'The Law of the Land: a review article', The Australian Journal of Anthropology, 14 (1): 97-110.

Wolfe, P. 1999. Settler Colonialism and the Transformation of Anthropology: The Politics and Poetics of an Ethnographic Event, Cassell, London. 